\title{
DOM AND NON-CANONICAL WORD ORDER IN ROMANCE: THE CASE OF GALICIAN
}

\author{
Brian Gravely ${ }^{* 1}$
}

\begin{abstract}
In this article, I investigate the link between VSO-VOS orders and differential object marking (DOM) via novel data from Galician. I present an analysis that sheds light on what may be required for a language to license DOM via movement, a requirement once thought necessary for licensing DOM that has recently been discredited on the basis of an overwhelming amount of cross-linguistic data (cf. Kalin 2018). I also show evidence for the variation regarding featural specification of DPs that must be differentially marked, adding to the highly variable factors that contribute to the appearance of DOM on nominal objects in natural language. Focusing on full DP objects, I conclude that licensing DOM in Galician is predicated on both the level of animacy of postverbal nominals and object shift in VOS configurations.
\end{abstract}

Keywords: Romance, differential object marking, word order, Galician, Agree, case assignment

\section{Introduction}

In this article, I investigate the link between VSO-VOS orders and differential object marking (DOM) via previously unaddressed data from Galician. I present an analysis that sheds light on what may be required for a language to license DOM via movement, a requirement once thought necessary for licensing DOM that has recently been discredited on the basis of an overwhelming amount of cross-linguistic data (cf. Kalin 2018). I also show evidence for the variation regarding featural specification of DPs that must be differentially marked, adding to the highly variable factors that attribute to the appearance of DOM on nominal objects in natural language. Focusing on full DP objects, I conclude that licensing DOM in Galician is predicated on both the level of animacy of postverbal nominals and object shift in VOS configurations

In section 2, I present the Galician data regarding the use of differential object marking (DOM) and the implications word order poses upon it. In section 3, I review the literature regarding object shift (OS) in Romance and examine the proposed postverbal subject positions. In section 4, I review several theories regarding feature checking, case assignment, and their implications for DOM. In section 5, I present my theory of DOM in Galician. Specifically, I follow the theoretical assumptions by Kalin (2018) regarding nominative case assignment and show that DOM in Galician is a strategy employed in order for nominative case to proceed in VOS order. Finally, I make concluding remarks regarding the implications for the investigation here and touch on future work.

\footnotetext{
*University of Georgia, U.S.A., bmg99472@uga.edu.

${ }^{1}$ I would like to thank Laura Kalin, Monica Alexandrina Irimia, and two anonymous reviewers for their insightful comments and suggestions on this article. I would also like to thank the audiences at The syntax and Semantics of Internal Arguments and the Linguistics Symposium of Romance Languages (LRSL) 50 for their comments. Most of all, I would like to thank Paula Cousillas and Fernando Torreiro for many intriguing discussions regarding this topic in Galician. All errors are my own.
}

Bucharest Working Papers in Linguistics XXII, 1, 5-31, e-ISSN 2392-8093, ISSN-L 2069-9239 DOI: 10.31178/BWPL.22.2.1 


\section{DOM and word order in Galician}

In this section, I show data from Galician regarding the syntactic nature of DOM. I review the most general tendencies laid out in the grammars of Álvarez et al. (2002) and Freixeiro (2006), specifically referencing the use of DOM in order to differentiate the direct object from the subject in non-canonical word orders. I show that Galician employs differential marking on its objects in a sparing manner. I conclude by showing that in Galician the feature responsible for licensing DOM in Galician is related only to animacy and specificity of the differentially-marked nominal plays no role.

\subsection{DOM in traditional Galician grammar}

Differential object marking has received little attention in traditional Galician grammar. Whilst one may argue that this is largely due to its scarce implementation, I shall show that the employment of DOM reveals a considerable amount about not only nominal licensing in Galician but also the need to revisit the general tendency to group dialects of Romance based on arbitrary geographical delineations (e.g. Gallego 2013). Regardless of their position in the sentence, direct objects in Galician typically go unmarked. This applies to the common SVO order (1a), the non-canonical orders VSO (1b) and VOS (1c), topicalized nominals such as those in clitic left-dislocated constructions (CLLD) (1d), and those that have undergone focus fronting (1e).
a.
O xardiñeiro podou
o pexegueiro
the gardener prune.PST.3SG the peach-tree
b. Podou o xardiñeiro o pexegueiro
prune.PST.3SG the gardener the peach-tree
c. Podou o pexegueiro o xardiñeiro
prune.PST.3SG the peach-tree the gardener
'The gardener pruned the preach tree.'
d. $\mathrm{O}$ pexegueiro, podouno o xardiñeiro
the peach-tree prune.PST.3SG-CL the gardener
'The peach tree, the gardener pruned it.'
e. O PEXEGUEIRO podou o xardiñeiro (non a maceira) the peach-tree prune.PST.3SG the gardener NEG the apple-tree 'The gardener pruned the peach tree (not the apple tree).'

Although my focus will not be on these examples, DOM is also prohibited in sentences in which both the subject and object nominals are inanimate.
a. $\mathrm{O}$ vento derrubou a parede
the wind topple.PST.3SG the wall
b. Derrubou o vento a parede
topple.PST.3SG the wind the wall


c. Derrubou a parede o vento

topple.PST.3SG the wall the wind

'The wind toppled the wall.'

d. A parede, derrubouna o vento

the wall topple.PST.3SG-CLACC.F.SG the wind

'The wall, the wind toppled it.'

$\begin{array}{lll}\text { e. A PAREDE } & \text { derrubou o vento } \\ \text { the walle } & \text { topple.PST.3SG the wind }\end{array}$

(non a árbore)

NEG the tree

'The wind toppled the wall (not the tree).'

Álvarez et al. (2002) and Freixeiro (2006) cite a select few cases in which direct objects, irrespective of animacy, may be differentially marked by the preposition $a$, the first being with personal pronouns. Not only must these be marked but they must be doubled by an agreeing accusative clitic.
a. Miroume
fixamente a min cando entrei
look.PST.3SG-CL.ACC.1SG closely DOM me when enter.PST.1SG
'He stared at me when I entered.'
b. Leváche-las a elas 0 ano pasado?
carry.PST.2SG-CL.ACC.F.PL DOM they the year last
'Did you take them last year?'

This is also applicable to elements such as indefinite pronouns (4a), especially when they are in a reciprocal relation, and wh-words with reference to people (4b), specifically when they do not pose a question but mark a relative clause. ${ }^{2}$ Both grammars also highlight the tendency to mark proper names (4c), although the absence of DOM does not render the sentence ungrammatical.
a. Aldraxábanse
uns a outros
disrespect.IMPV.3PL-CL.REFL.3SG ones DOM others
'They insulted one another.'
b. Falaba cunha muller (a) quen eu non
talk.IMPV.3SG with-a woman DOM who I NEG
vira endexamais
see.PRFV ever

'She was talking with a woman that I had never seen before.'

\footnotetext{
${ }^{2}$ It is worth noting that DOM is not required in this construction, although this seems largely dependent on the verb used. A verb such as ver 'to see' does not require the relativized object to be marked; however, this marking renders the sentence unacceptable with the verb coñecer 'to know.

(i) Falaba cunha muller (*a) quen eu non coñecía speak.IMPV.3SG with-a woman DOM who I NEG know.IMPV.1SG 'She was speaking with a woman I didn't know.'
} 


c. Non sabían canto quixen (a) Lúa
NEG know.IMPV.3PL how love.PST.1SG DOM Lúa
'They didn't know how much I loved Lúa.'

Before moving to the examples that will serve as the crux of my argument in this article, I wish to reflect on the differential marking shown in the previous examples as these are neither feature-related nor compositionally triggered in the same way as the instances of DOM I concentrate on in this investigation. Contrary to what has been assumed in previous generative theories, I claim that these nominals require special licensing as objects due to their status as heads and not phrases. I recognize that this is a loaded statement that cannot be fully explored for reasons of space, but a simple explanation with respect to demonstratives and adjectival nominals is shown below.

Atopei (*a) outros/Ø os outros moi avellados
find.PST.1SG DOM others the others very old
Intended: 'I noticed others/the others past their prime.'
Non vemos $(* \mathbf{a})$ eses/Ø eses rapaces por ningures
NEG see.PRS.1PL DOM those those boys by nowhere
'We don't see those/those boys anywhere.'

In (5), outros 'others' must be introduced by a case marking preposition when alone; however, DOM is not necessary when it is the complement of the determiner os 'the'. The same is found with the demonstrative eses 'those' when it does and does not introduce an NP complement (6). Although one may come to the assumption that this has something to do with the lack specificity of these bare referents based on (5), the demonstrative in (6) is specific and still requires marking. I attribute these data to a structural difference (i.e. whether outros and eses are lone $\mathrm{D}^{\mathbf{o}}$ heads rather than parts of full-fledged DPs). ${ }^{3}$

\subsubsection{DOM with full DP nominals}

I have shown that nominal objects that are simple $\mathrm{D}^{\mathbf{o}}$ heads behave in a peculiar manner that require a separate analysis than that which I present in this section regarding DP objects. Whereas Álvarez et al. (2002) highlights peripheral cases in which semantics seem to play a significant role even in SVO order, Freixeiro (2006: 631) takes a stricter syntactic approach:

In sequences in which the constituents do not follow the typical order (subject + verb + object), producing ambiguity in identifying the function of the subject and

\footnotetext{
${ }^{3}$ Similar claims have been made by Rodríguez Mondoñedo (2007) regarding certain wh-words (e.g. quién 'who') and negative polarity nominals (e.g. nadie 'no one') in Spanish, although, at first glance, Galician seems to be more uniform than Spanish in this respect. Due to space restrictions, I leave this topic for further research.
} 
verb complement $[\ldots]$ when a preposition is not used, it is understood that the subject appears first and then the object complement

The type of ambiguity referred to by Freixeiro deals with distinguishing between two constituents with a [+HUMAN] feature. ${ }^{4} \mathrm{He}$ notes that the object nominal is marked neither in SVO strings (7) nor in CLLD constructions (8):
Os pais educan
os fillos
the parents educate.PRS.3PL the children
'Parents educate (their) children.'
Os fillos, edúcanos
os pais
the children educate.PRS.3PL-CL.ACC.M.PL the parents
'Their children, parents educate them.'

However, when both nominals bearing a [+HUMAN] feature are in postverbal position and no nominal is overtly marked, the natural order is that of VSO.
Educan
os pais os fillos
educate.PRS.3PL the parents the children
'Parents educate (their) children.'
Educan
os fillos
os pais
educate.PRS.3PL the children the parents
'Children educate (their) parents.'

The meaning in (9) is reversed in (10) when the two postverbal nominals switch order and neither is marked, maintaining a VSO interpretation.

In Gravely (2019), I noted that the most common order when both nominals follow the verb is VOS, allowing focal stress to fall on the last constituent of the sentence. ${ }^{5}$ Only in this order do we find obligatory DOM.
Viron $\quad *$ os/ós
nenos as nenas
see.PST.3PL the/DOM-the boys the girls
'The girls saw the boys.'
Sacamos
*as/ás
vellas os coidadores $^{6}$
remove.PST.1PL the/DOM-the elderly the care-takers
'Us care takers carried out the elderly women.'

\footnotetext{
${ }^{4}$ This ambiguity may also be extended to [+ANIMATE], as well. I return to this in section 5.

${ }^{5}$ The original observation was made thanks to much insightful discussion with Fernando Torreiro and Xosé Ramón Freixeiro.

${ }^{6}$ Interestingly, Galician has an additional way of marking complements in these constructions by way of incorporation of the determiner:

(i) Sacamo-las vellas os coidadores

remove.PST.1PL-CL.PL elderly the care-takers

Space limitations preclude me from adding the details of determiner cliticization as a case-marking strategy. I leave this for a subsequent analysis.
} 
In (11) and (12), the object nominal is marked by way of incorporation of the determiner onto the preposition $a$. This is realized by the phonological alternations of the determiners as shown below:

$$
\begin{array}{llrl}
\text { a. } & \text { los } / \rightarrow \text { os } / & \text { (unstressed close-mid vowel } \rightarrow \text { open-mid vowel) } \\
\text { b. } & \text { /as } / \rightarrow[\text { a:s }] & \text { (unstressed central vowel } \rightarrow \text { stressed central vowel) }
\end{array}
$$

When the DP is headed by an indefinite determiner (14) or a quantifier (15), the preposition is phonologically distinct:

Po-la beira levou *(a) un descoñecido
by-the bank carry.PST.3SG DOM a stranger
meu curmán
my cousin
'My cousin carried a stranger along the riverbank.'
Despedistes *(a) toda-las enfermeiras os médicos
release.PST.2PL DOM all-the nurses, the doctors
'You doctors sent home all of the nurses.'

The data in (14) and (15) follow the previous observations that object nominals bearing a [+HUMAN] feature in VOS strings require DOM regardless of the (in)definiteness or quantification of the DP.

\subsubsection{Specificity plays no role}

In contrast to what I show for Galician, differential marking of nominals in Spanish has been shown to involve more than one scale as described by Aissen (2003). Notably, both animacy and specificity play a role in determining whether objects are marked in Spanish.

$$
\begin{aligned}
& \text { Busca a /Ø una trabajadora } \\
& \text { search.PRS.3SG DOM/Ø a worker } \\
& \text { 'María is looking for a worker.' }
\end{aligned}
$$

When the object una trabajadora 'a worker' is differentially marked, there is a [+SPECIFIC] reading (i.e. María knows the worker she is searching for). When there is no marking, however, it is understood that María does not know the worker she is looking for. This sensitivity toward specificity is non-existent in Galician.

$$
\begin{array}{llll}
\text { Procura a } / * \varnothing \text { unha } & \text { traballadora } & \text { María } \\
\text { search.PRS.3SG DOM/ } \varnothing \text { a } & \text { worker } & \text { María } \\
\text { 'María is looking for a worker.' } & &
\end{array}
$$


As seen in (17), the object nominal must be marked regardless of the specificity surrounding unha traballadora 'a worker'. The only aspect that matters in determining whether the object gets marked is the animacy of the object.

\subsection{Concluding remarks}

In this section, I offered novel data from Galician regarding the use of differential object marking. I showed that only in VOS order is DOM required on full DP nominals. I also showed that, unlike in Spanish, specificity is not a factor in determining whether a nominal must be marked; only animacy is relevant. In the subsequent sections, I apply theories related to non-canonical word orders and DOM cross-linguistically to these data.

\section{Word order in Romance}

In this section, I review basic word order patterns found in so-called Western (i.e. Spanish, Portuguese, Galician) and Central/Eastern (i.e. Catalan, Italian) Romance (see. Gallego 2013), specifically that the former may license both VSO and VOS orders whilst the latter may only license VOS order. ${ }^{7}$ I compare past accounts that approach word order as the individual movement of each argument DP (Ordóñez 2007, López 2012, Costa 2004, a.o.) versus those that opt for pied-piping of various constituents (Gallego 2013, Belletti 2004, Zubizarreta 1998, a.o.). I conclude that there is evidence that VOS arises in all Romance varieties from object shift, even in those that do not license VSO order (pace the assumptions made in Gallego's "VOS-VSO Generalization"). It follows that VSO order relies on further movement of the subject to a peripheral site between $\mathrm{Spec}, \nu \mathrm{P}$ and $\mathrm{T}^{\mathrm{o}}$ (as proposed in Ordóñez 2007).

\subsection{VOS data}

\subsubsection{VP-fronting}

The Romance varieties mentioned above share not only the unmarked word order SVO but also the ability to license the non-canonical word order VOS. ${ }^{8}$

Llegeix el diari ton pare
read.PRS.3SG the newspaper your father
'Your father reads the newspaper.'

\footnotetext{
${ }^{7}$ Due to the fact that French is not a null-subject language, I leave it out of my word order analysis, as others have done, due to the effects this has on variable word order. Romanian, another Romance language that licenses both VSO and VOS orders, is excluded for reasons of space.

${ }^{8}$ Belletti (2004) has claimed that VOS in Italian is only grammatical under certain circumstances, but others have shown there to be variability depending on the dialect.
} 
b. Tienen el móbil las chicas Spanish have.PRS.3PL the mobile the girl 'The girls have the phone.'

c. Fixeron a tarea os neno Galician do.PST.3PL the homework the boys 'The boys did the homework.'

d. Disse a verdade o Pedro say.PST.3SG the truth Pedro 'Pedro said the truth.'

$\begin{array}{lll}\text { e. } & \text { Capirà problema Gianni } \\ \text { understand.FUT.3SG the problem Gianni }\end{array}$ Italian 'Gianni will understand the problem.'

There have been two approaches to deriving VOS orders in Romance: (i) object shift of the direct object over the subject (Costa 2000, 2004, Ordóñez 2007, a.o.), and (ii) VP-fronting of the verb and object to a position higher than the subject (Belletti 2004, Gallego 2013, a.o.). It is important to note that Catalan and Italian are the languages that have been analyzed as involving VP-fronting, which is well-motivated in principle: if the object is moved phrasally with the verb, this explains the lack of VSO order in these languages, as there would be no projection between the verb and the object to which the subject could move, as shown in (19). ${ }^{9}$

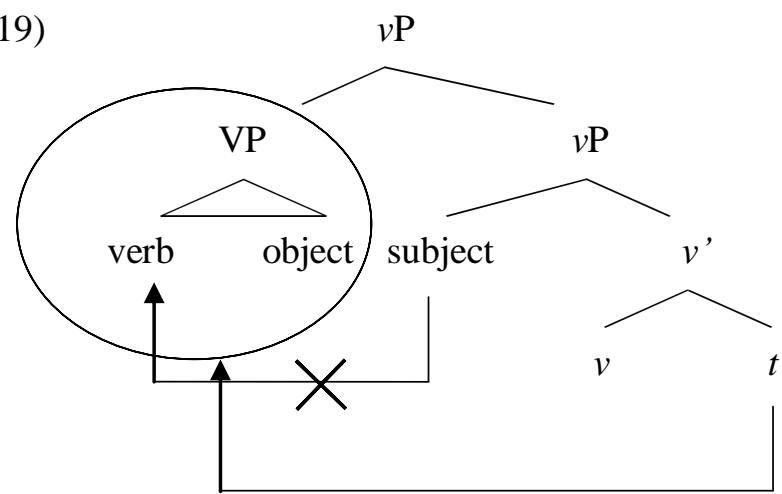

As pointed about by Gallego (2013), support for the VP-fronting strategy comes from several observations. First, shifted objects have been shown to bind into post-verbal subjects in some languages, which should not be available for VOS orders in Catalan via VP-fronting, as the object is too far embedded into the moved VP phrase. A language that undergoes object shift instead of VP-fronting will permit this binding. We find this binding, however, in Galician (20a), Spanish (20b), and Catalan (20c). ${ }^{10}$

\footnotetext{
${ }^{9}$ Although the accounts presented by Belletti and Gallego differ with respect to the label of the projection the VP merges to, I take them to be one and the same due to the technical nature of the movement proposed.

${ }^{10}$ Gallego (2013: 416) marks (20c) sentence as "??" and, in turn, questions object shift in Catalan as a VOS strategy due to the debatable binding of the object into the subject. However, an anonymous reviewer points
} 
(20)
a. Recolleu cada coche o seu dono pick-up.PST.3SG each car the its owner
b. Recogió cada coche su propietario pick-up.PST.3SG each car its owner
c. Va recollir cada cotxe el seu propietari go.PRS.3SG collect.INF each car the its owner 'Its owner picked up every car.'

The second point made by Gallego concerns extraction out of the object, which should be impossible if the object is moved within the phrasal VP as proposed for Catalan (21a). Again, Spanish (21b) and Galician (21c) show no restriction with this movement but in Catalan (21a) the phrase's grammaticality is questionable.

a.

$$
\begin{aligned}
& \text { [??Quina pel•lícula }]_{\mathrm{k}} \text { dius } \text { que no va } \\
& \quad \text { which film say.PRS.2SG COMP NEG go.PRS.3SG } \\
& \text { veure tota } t_{\mathrm{k}} \text { en Joan? } \\
& \text { see.INF all the Joan }
\end{aligned}
$$

b. [Que película $]_{k}$ dices que no vio what film say.PRS.2SG COMP NEG see.PST.3SG toda $t_{\mathrm{k}}$ Juan?

all Juan

c. [Que película $]_{\mathrm{k}}$ dis que no viu what film say.PRS.2SG COMP NEG see.PST.3SG toda $t_{\mathrm{k}}$ Xan? all Xan 'What movie do you say that Xan did not see all of?'

From these data, we can see that the VP-fronting movement for Catalan seems dubious due to the fact that common binding effects hold up in all three languages examined above, although extraction out of objects may result in more opaque judgements. There is, however, evidence that causes problems for a VP-fronting analysis on a larger scale than just that of VOS order.

\subsubsection{Obligatory object shift and VOS order}

Ordóñez (2007) offers data from Catalan and Spanish with regard to the availability of postverbal subject positions in these two languages. ${ }^{11}$ Contrary to Gallego (2013), Ordóñez argues that object shift in both Catalan and Spanish are obligatory in order to derive VOS order; it is the ability of the subject, however, to move from its base-

\footnotetext{
out that his/her native intuitions point to this being a perfectly grammatical construction in Catalan, ultimately weakening Gallego's argument that VOS order is not due to object shift.

${ }^{11}$ I follow Ordóñez's examples in Spanish for expository reasons. Due to space restrictions, I cannot provide all of the corresponding examples in Galician; however, I confirm that Galician licenses the same subject positions as Spanish.
} 
generated position to a higher postverbal landing site between $\mathrm{Spec}, v \mathrm{P}$ and $\mathrm{T}^{\mathrm{o}}$ that distinguishes languages that license VSO and VOS from those that only license VOS. He refers to this projection as SubP. ${ }^{12}$

$$
[\mathrm{TP} \ldots[\mathrm{SubP} \ldots[v \mathrm{P} \ldots]]]
$$

Ordóñez provides examples of several constructions in which the subject moves to SubP in Spanish, but not Catalan, solidifying his argument for there being the availability of a higher projection for subjects in Spanish. For example, Spanish permits subjects to precede adjectival predicates of small clauses (23a), to be sandwiched in between both modal auxiliaries and infinitives (23b) and infinitives and their complements (23c), to precede object quantifiers as a floating quantifier (23d), and to precede infinitival complements in restructuring constructions $(23 \mathrm{e}):^{13}$
a. Resultó el alumno desprevenido seem.PST.3SG the student unprepared 'The student seemed unprepared.'
b. Ayer no podía Carlos dormirse yesterday NEG be-able.IMPV.3SG Carlos sleep.INF-CL.REFL.3SG 'Yesterday Carlos wasn't able to fall asleep.'
c. No debería coger tu hermano el tren NEG should.COND.3SG catch.INF your brother the train 'Your brother shouldn't catch the train.'
d. Las gatas lo comían todas todo the cats CL.ACC.M.SG eat.IMPV.3PL all.PL everything 'All of the cats ate everything.'
e. Les hicieron leer los profesores el periódico CL.DAT.3PL do.PST.3PL read.INF the professors the newpaper 'The professors made them read the newpaper.'

Catalan, however, is unable to prepose the subject in any of these constructions, showing the ability to only license a low subject position. Like Gallego (2013), I take this position to be its base-generated position, Spec, $\nu \mathrm{P}$.
a. *Resulten les cases molt petites result.PRS.3PL the houses very small 'The houses are very small.'
b. *Per sort va poder la Carlota dormir for luck go.PRS.3SG be-able.INF the Carlota sleep.INF 'Luckily, Carlota was able to sleep.'

\footnotetext{
${ }^{12}$ Much like Belletti (2004), Ordóñez takes a cartographic approach to the sub-TP area. Although I do not adopt a cartographic approach here, I use his projection labels for expository purposes.

${ }^{13}$ Ordóñez also analyzes subject pronouns that fall between the auxiliary haber 'have' and past participles, permitted in Spanish but not in Catalan; however, I leave this aside due to my focus on full DPs here.
} 


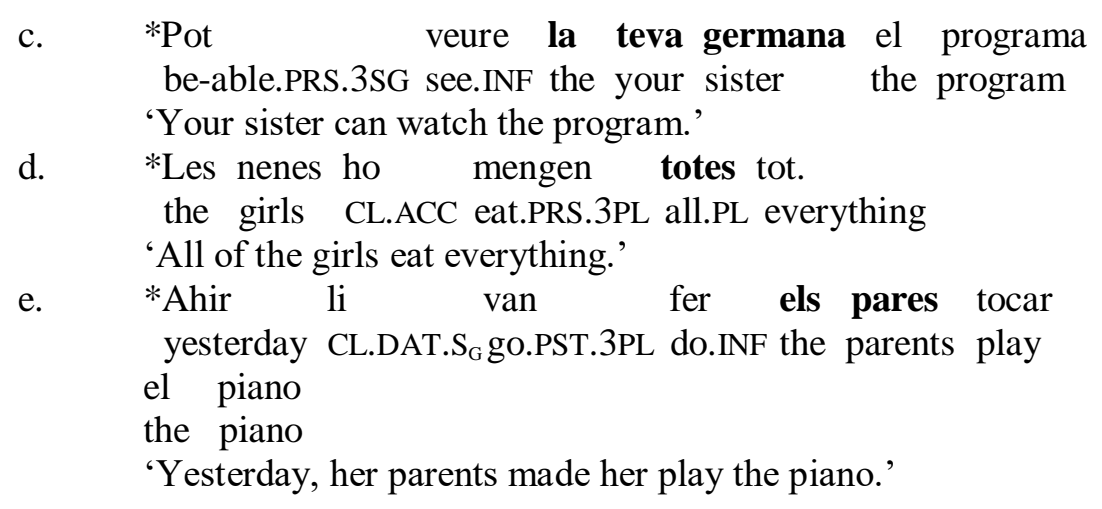

The data from (23) and (24) contrast starkly, showing a clear inability of the subject in Catalan to raise to the same position as in Spanish across a number of constructions. The corresponding constructions that are grammatical in Catalan, however, pose the same problem seen in (19): if the object is fronted with the verb in instances of VOS order, it is unclear how the predicative adjective in small clause constructions fits the bill in this VP-fronting strategy. ${ }^{14}$
Resulten molt petites les cases
result.PRS.3PL very small.PL the houses
'The houses are very small.'

In the analysis of Gallego \& Uriagereka (2016), the predication of small clauses is brought about due to the fact that both the subject and its predicate are externally merged as mutual c-commanding sisters as in (26). These authors claim that within the small clause the predicative relation is established, whilst the copular verb is nothing more than a marker of tense. ${ }^{15}$

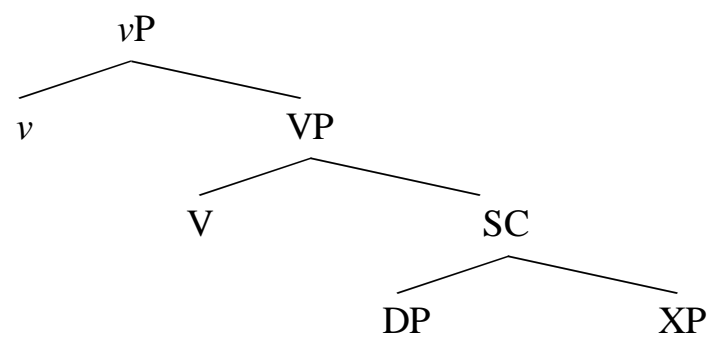

\footnotetext{
14 That is to say, if remnant movement is unacceptable in Catalan in instances of VOS per Gallego's observations, it is unclear how Catalan would accept remnant movement of the type seen in small clauses. ${ }^{15}$ Gallego \& Uriagereka (2016) propose an additional projection ("X") that incorporates into the verbalizing head $v$ in order to distinguish the copulas estar and ser. I exclude this here, as nothing hinges on this in my analysis.
} 
Assuming that the subject DP leaves the small clause for Spec, $\nu \mathrm{P}$, the VP-fronting movement that would produce the grammatical order in (25) would proceed as in (27):

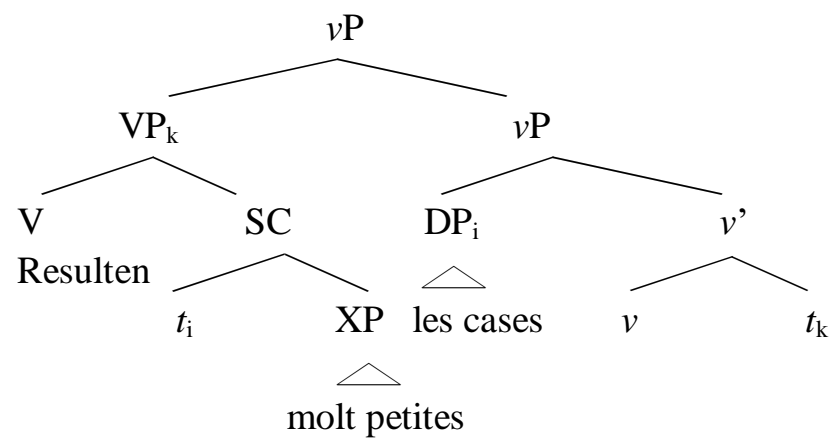

The problem here is the obligatory remnant movement of the trace of the subject DP, an approach that Gallego (2013: 412) rejects outright for his VP-fronting analysis.

Another issue worth mentioning is the link between reconstruction (such as the causative construction in (24e)) and the VP-fronting analysis. We have seen that, contrary to Ordóñez (2007), Belletti (2004) and Gallego (2013) take VP-fronting to be the strategy by which VOS order is derived in Italian and Catalan rather than object shift. Along these lines, Belletti (2017) argues for the same VP-fronting strategy for reconstruction in Italian.
Maria farà
[mangiare il gelato] al bambino
Maria make.FUT.3SG eat.INF the ice-cream to-the child
'Maria will make the child eat ice cream'

(Belletti 2017: 16)

In (28), the infinitival verb phrase mangiare il gelato 'eat the ice cream' is fronted past its subject, the latter bearing dative case from its base-generated position in Spec, $v$ P. It's important to note that, as many have done in recent minimalist theory, Belletti takes causative constructions to be derivationally monoclausal, with the verb fare, being "semifunctional", heading its own $v_{\text {CAUs }}$ projection above the lexical $v \mathrm{P} .{ }^{16}$ This monoclausal analysis provides a streamlined comparison between single-verb sentences and those of the reconstruction type viewed here; nevertheless, we may observe unexpected patterns in which the dative-marked subject of the infinitive may precede the VP mangiare il gelato 'eat the ice cream' (29a) or come between the verbal predicate and its internal argument $(29 b){ }^{17}$

\footnotetext{
${ }^{16}$ See Ciutescu (2013) for a biclausal proposal for reconstructed sentences in Romanian.

${ }^{17}$ I thank Mattia Pistone for his judgements of these constructions.
} 


Maria farà al bambino] mangiare il gelato
Maria make.FUT.3SG to-the child eat.INF the ice-cream
b. Maria farà mangiare [al bambino] il gelato
Maria make.FUT.3SG eat.INF to-the child the ice-cream

Although (29a) doesn't pose a problem for the VP-fronting approach, (29b) certainly does. These data show that the dative-marked causee subject may intervene between the infinitive and its object, which is the opposite of what we have seen from the Catalan-Italian-type languages and pairs with Galician (30) and the other Western Romance languages. In these varieties, the dative-marked causee subject may appear before, in between, or after the infinitival predicate and its argument.
a. María fixo
María make.PST.3SG to-the boy
[ó neno] xantar o xeado
b.
María fixo xantar [ó
eat.INF the ice-cream
María make.PST.3SG eat.INF to-the boy the ice-cream
c. María fixo xantar o xeado [ó neno]
María make.PST.3SG eat.INF the ice-cream to-the boy
'María made the boy eat the ice cream.'

Based on what has surfaced here, I take VOS order in all aforementioned languages to be derived from obligatory object shift rather than VP-fronting. ${ }^{18}$

\subsection{VSO data}

\subsubsection{VSO: More about the object than the subject}

It has been noted above that VSO orders are excluded in Catalan and Italian, a fact that makes object shift mandatory in postverbal subject constructions. As for languages that have VSO, however, there has been no consensus in the literature as to the derivational movements needed in order to license said word order. Gallego (2013), for example, takes object shift to be obligatory in these Romance varieties. If the object is obligatorily shifted to a peripheral specifier of $v \mathrm{P}$, then VSO orders must come about by an additional movement of the subject from its base-generated position to a projection further up in the phrase marker but below T ${ }^{\mathrm{o}}{ }^{19}$ Examples such as those in (31a) and (31b) would be represented as (32a) and (32b), respectively.

\footnotetext{
${ }^{18}$ It may be that Italian works differently than Catalan, which would further dismantle attempts to geographically divide phenomena amongst the Romance languages in assuming that the Central/Eastern Romance languages pair one way, whilst Western Romance languages pair another way (e.g. Gallego 2013). Another possibility is that there exists no correlation between causative constructions and regular transitive constructions; however, it is not clear to me why causatives alone would cause the breach in VP-fronting that we see here. I leave these questions for further investigation.

${ }^{19}$ Gallego (2013: 440) addresses the fact that Ordóñez (2007) labels this projection SubjP in a cartographic approach, which he in turn interprets as a further specifier of $v \mathrm{P}$. I remain agnostic as to the label of the projection, as the data seem to support it being one in the same, and simply label it XP.
} 

a. Colleu tóda-las pitas Xabier
b. Colleu Xabier tóda-las pitas grab.PST.3SG Xabier all-the hens 'Xabier grabbed all of the hens.'

a. $\quad\left[{ }_{\mathrm{TP}}\left[\mathrm{T}-\nu-\sqrt{ } R\right.\right.$ Colleu $_{\mathrm{i}}\left[{ }_{\nu \mathrm{P}}[\mathrm{DP} \text { toda-las pitas }]_{\mathrm{k}}\left[{ }_{\nu \mathrm{P}}\right.\right.$ Xabier $\left.\left.\left.\left.\left[{ }_{v} t_{\mathrm{i}}\left[t_{\mathrm{k}} \ldots\right]\right]\right]\right]\right]\right]$

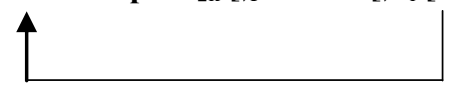

b. $\quad\left[\mathrm{TPP}\left[\mathrm{T}-v-\sqrt{ } R\right.\right.$ Colleu $\left.\left._{\mathrm{i}}\left[\mathrm{XP}\left[{ }_{\mathrm{DP}} \text { Xabier }\right]_{\mathrm{g}}\left[{ }_{v \mathrm{P}}[\mathrm{DP} \text { tóda-las pitas }]_{\mathrm{k}}\left[{ }_{v \mathrm{P}} t_{\mathrm{g}}\left[{ }_{v} t_{\mathrm{i}}\left[t_{\mathrm{k}} \ldots\right]\right]\right]\right]\right]\right]\right]$

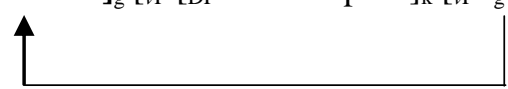

With the movement of the subject from its base-generated position across the object DP in (32b), VSO is derived. ${ }^{20}$

It is worth questioning the reason for obligatory object shift in Romance in these instances. Gallego (2013) highlights the need to account for Holmberg's Generalization (Holmberg 1986, 1999) due to the lack of object shift when the lexical verb remains on $v^{\circ}$ in progressive constructions. ${ }^{21}$
a. Ayer estaba Juan leyendo un libro yesterday be.PST.3SG Juan read.PROG a book
b. *Ayer estaba [un libro] Juan leyendo $t_{\mathrm{i}}$ yesterday be.PST.3SG a book Juan read.PROG 'Juan was reading a book yesterday'

(Gallego 2013: 411)

The data in (33) suggest that the only viable option is for the internal argument to remain below the verb leyendo on $v^{\text {o }}$, however, Gallego provides further evidence that object shift should actually be accounted for by the object remaining below the verb (not necessarily below the verb in the $v \mathrm{P}$ layer), as there are constructions in which the subject is in clause-final position and the object has shifted over it (34a). Even though the object has clearly moved to a $v \mathrm{P}$-peripheral site above the subject, the object may not precede the lexical verb (34b).
a.
Ayer
estaba
leyendo [un libro] Juan $t_{\mathrm{i}}$
b.
yesterday be.IMPV.3SG read.PROG a book Juan
*Ayer estaba [un libro] leyendo Juan $t_{\mathrm{i}}$ yesterday be.IMPV.3SG a book read.PROG Juan 'Juan was reading a book yesterday.'

\footnotetext{
${ }^{20}$ As mentioned above, Ordóñez (2007) claims that the subject always leaves its base-generated position; thus, VSO order would proceed as in (i) and VOS order as in (ii).

(i) $\quad\left[\mathrm{TP}_{\mathrm{T}}\left[\mathrm{T}_{-\mathrm{v}} \sqrt{ }{ }_{R}\right.\right.$ Colleu $\left.\left.\left._{\mathrm{i}}\right]\left[\mathrm{XP}[\mathrm{DP} \text { Xabier }]_{\mathrm{g}}\left[{ }_{\mathrm{pP}} \text { [DP toda-las pitas }\right]_{\mathrm{k}}\left[{ }_{v \mathrm{P}} t_{\mathrm{g}} \ldots t_{\mathrm{k}}\right]\right]\right]\right]$

(ii) $\quad\left[\mathrm{TP}_{\mathrm{TP}}\left[\mathrm{T}_{-}-\sqrt{ } R\right.\right.$ Colleu $\left.\mathrm{i}_{\mathrm{i}}\right]\left[\mathrm{WP}[\mathrm{DP} \text { toda-las pitas }]_{\mathrm{k}}\left[\mathrm{XP}[\mathrm{DP} \text { Xabier }]_{\mathrm{g}}\left[{ }_{v \mathrm{P}} t_{\mathrm{k}}\left[{ }_{\nu \mathrm{P}} t_{\mathrm{g}} \ldots t_{\mathrm{k}}\right]\right]\right]\right]$

${ }^{21}$ Although he does not specify, it seems that Gallego takes Holmberg's original formulation based on evidence from Scandinavian: the object cannot leave the $v$ P layer unless $v^{\circ}$ moves. For a slightly different formulation, see Sheenan et al. (2017), specifically section 10.5 .
} 
These data lend themselves to an account of linearization and legibility, highlighted in Sheenan et al. (2017). Following the theory laid out in Fox \& Pesetsky (2005), these authors claim that verb movement is free and without consequence for its object, whereas the movement of the object is predicated on verb movement.

There are several details regarding the analyses above that are worth pointing out before continuing. First, taking object shift to be obligatory, it is clear that the noncanonical subject position in VSO strings is dependent on the movement of the object. VOS order prevents the subject from leaving its base-generated position, whilst VSO order forces the subject to move. Although Ordóñez (2007) offers data that support a very strong case for a designated position for the postverbal subject in Spanish, I fail to see the connection between this position and object shift. Perhaps the most widely accepted reason for which the object vacates the $v \mathrm{P}$ is the observation made by Diesing (1992) in which she argues that the nominal must exit the lexical layer in order to escape existential closure; however, the examples provided by Gallego, specifically (34), show further reasoning for assuming obligatory object shift in Romance.

\subsection{Concluding remarks}

In this section, I have shown evidence for an obligatory-object-shift approach to VOS order across Romance varieties. For those languages that are able to license VSO order, I followed Ordóñez (2007) in claiming that there exists a further projection between Spec, $\nu \mathrm{P}$ and $\mathrm{T}^{\mathrm{o}}$ to which the subject moves, a fact support by a considerable number of varying constructions involving the subject leaving its base-generated position in Spec, $v \mathrm{P}$.

\section{Case licensing}

In this section I briefly discuss the most common reasons for why nominals are or are not differentially marked. Upon adopting the approach in Kalin (2018), I lay out the details of this proposal, as well as discuss the reasons for why $\mathrm{P}^{\circ}$ must serve as the DOM licenser in Romance. I explain the details of Preminger's $(2011,2014)$ "obligatoryoperations model" and how we may account for subject licensing under these terms.

\subsection{DOM licensing}

A great deal of literature has focused on hypotheses as to when DOM arises, the functional head that licenses it, and related theoretical underpinnings (e.g. its relationship to case). Authors following the Chomskyan tradition of case assignment being intertwined with $\varphi$-feature agreement assume the former to be an instance of abstract case. DOM arises, thus, from a morphologically richer functional head which assigns case to the marked nominal (often taken to be $v^{\circ}$ ). Building on this, some also take movement to a particular position in the derivation to be a requirement by which DOM surfaces, as in López (2012), as well as the idea that some objects are not DPs but NPs and, thus, invisible to licensing heads (Ledgeway et al. 2019). In recent approaches to DOM (and 
case), however, there is more of a straightforward surface approach: nominals that show DOM have been assigned case, whilst some nominals simply go unlicensed and unmarked.

Kalin (2018) offers a thorough cross-linguistic analysis of main and secondary licensers of all possible nominals, both subjects and objects. Her analysis is predicated on three arguments: (i) all nominals are available for licensing (pace the ideas in Danon 2006, a.o.) although not all nominals require licensing; (ii) the objects that are licensed should reveal licensing constraints in a given language; (iii) most languages resort to an optional secondary licenser when it comes to objects, whereas $\mathrm{T}^{\mathbf{o}}$ seems to always license its subject across the board (due to the locality of the latter to $\mathrm{T}^{\circ}$ ). ${ }^{22}$

As I adopt Kalin's approach, a few comments are in order. First, the idea that all nominals are visible to the derivation and, therefore, are eligible to be licensed seems correct. It is important to emphasize that this is regarding case, not $\varphi$-feature agreement, as the latter may bypass certain nominals based on their $\varphi$-set and continue to probe for a more complex nominal with respect to feature specification, for example. There are numerous ways to show this, but I provide a specific account of how this may work in section 5. Second, and possibly most importantly for my work here, the idea that observations regarding the nominals that are licensed in a language $L$ should tell us something about licensing in said language concedes us the ability to make languagespecific determinations about what features or syntactic configurations trigger DOM. For example, Spanish relies on features related to both animacy and specificity in order to license nominal objects, whereas DOM in Galician stems from a combination of both the featural specification of animacy and a particular syntactic configuration of nominals in the same local domain. Third, regarding the idea that a secondary licenser may be morphophonologically identical to other markers should not hinder us from identifying its purpose in the syntax or the distinction between different kinds of nominals that are selected by each marker. Kalin makes a valuable observation that most markers of DOM are utilized elsewhere in the syntax, but it seems a mistake to assume that these configurations are somehow in competition or fight for the same projection (pace claims by Ormazábal \& Romero 2019). ${ }^{23}$ I touch on this in section 4.2 with respect to the projection that introduces the differential marker in Romance.

\footnotetext{
${ }^{22}$ An anonymous reviewer argues that Kalin's last argument cannot be correct, as we see that $\mathrm{T}^{\mathbf{o}}$ cannot license "all types of subjects," citing cases of medio-passives in Spanish (see Mendikoetxea 2008). Space precludes me from addressing all of the nuances of this statement, but it is important to remember that for my investigation, I am concentrating on the interweaving of subject licensing with DOM in constructions in which both nominals are overt (as these effects do not arise in Galician when one or another is elided) which differs fundamentally from Mendikoetxea's work. In addition, Kalin's approach deals with much of the same construction type (i.e. two overt nominals and their locality to potentially licensing heads in a given language), and is, therefore, a solid theoretic base upon which I may compare how DOM arises in Galician. We know from further evidence (e.g. Preminger 2014 on Kichean Agent Focus) that probes do not search for goals marked "subject" or "object" but instead seek DPs with their feature specification. My point here is not to argue that all subjects are licensed by $\mathrm{T}^{\mathbf{o}}$ but instead show how DOM may seemingly aid in subject licensing when the subject is, in fact, the furthest available goal from the probe on $\mathrm{T}^{\circ}$.

${ }^{23}$ A reviewer questions whether we can say "most languages" do this, citing Turkish as an example of a language that does not have a DOM marker that doubles elsewhere in the language. Kalin (2018: 127) indeed notes that Turkish has a non-syncretic DOM marker, but I concur with her observation that most languages' DOM marker is evidenced elsewhere, particularly that of a dative marker or adposition. This is certainly the case in Romance.
} 


\subsection{What licenses DOM in Romance?}

I assume that the optional secondary licenser Kalin (2018) makes reference to is $\mathrm{P}^{\mathbf{o}}$ in Romance, $p e$ for Romanian and $a$ for the rest of the Romance varieties. Other labels have been proposed such as $\mathrm{K}^{\mathrm{o}}$ heading a KP projection (Richards 2010, Colomina 2020, López 2012) and $\mathrm{Appl}^{\circ}$ heading an applicative phrase (Ormazábal \& Romero 2013). There is little difference from a theoretical standpoint between $\mathrm{P}^{\circ}$ and $\mathrm{K}^{\circ}$, and $\mathrm{I}$ have nothing more to say about it here; however, claiming nominals exhibiting DOM to be marked by an $\mathrm{Appl}^{\circ}$ head makes problematic assumptions. Cross-linguistically, particularly in Romance, applicative phrases typically consist of a clitic occupying the head of the projection (or occasionally a phonologically null head) with a co-referential full DP in its specifier. Barring marginal Spanish dialects such as that of Argentine Spanish, nominals identified as direct objects do not double when found in A-positions in Romance. ${ }^{24}$ Furthermore, the dative marking on the full DP is obligatory and not based on features of the nominal it selects (i.e. it is uniform, not differential). As Kalin notes, this fact leads us to the conclusion that applicative phrases seem to license their own arguments. ${ }^{25}$

\subsection{Geometric feature bundles and nominative case assignment}

Although I take nominative case to be a reflex of Agree between $\mathrm{T}^{\mathbf{0}}$ and its DP subject, the implementation of Agree that I adopt differs from that of Chomsky (2000, 2001). Instead, I adopt the feature-geometric approach to valuation as in Preminger $(2011,2014)$. This account is laid out below.

In Preminger $(2011,2014)$, the agreement mechanism found in the narrow syntax relies on a probe-goal dependency for valuation of the probe; however, the main differences that are of concern here are i) the lack of derivational crash when the probe is unable to find a goal with which to agree (what Preminger refers to as Chomsky's "derivational time-bombs model"), and ii) the features found on the goal (and copied to the probe) extending beyond the typical [NUMBER], [GENDER], and [PERSON] features typically referred to in generative grammar. With respect to this last modification, Preminger refers to the feature-geometric approach as outlined in Harley \& Ritter (2002), McGinnis (2005), a.o. Building off of observations from Lidz (2006), Kalin (2019) highlights the importance of accounting for projections relating to the degrees of specificity and animacy within the DP (e.g. participant, person, etc.). Taking these projections to be prominent within the featural composition of nominals, these features should be represented and taken into account when the probe searches for a viable goal. A basic feature-geometric representation can be seen in (35).

\footnotetext{
${ }^{24}$ To reiterate, I specifically refer to full DPs here, i.e. third-person referents. I remain unconvinced as to the status of first- and second-person pronouns in Romance as DPs and not $\mathrm{D}^{\circ} \mathrm{s}$ as generally assumed in generative theory.

${ }^{25}$ A reviewer questions the validity of this statement, citing work from Pineda (2020) as counterevidence. I find Pineda's argument unconvincing and her analysis largely orthogonal to my determining whether differentially marked objects are in fact selected by an applicative phrase or a prepositional phrase.
} 
(35) Feature-geometric bundle (adopted from Kalin 2019)

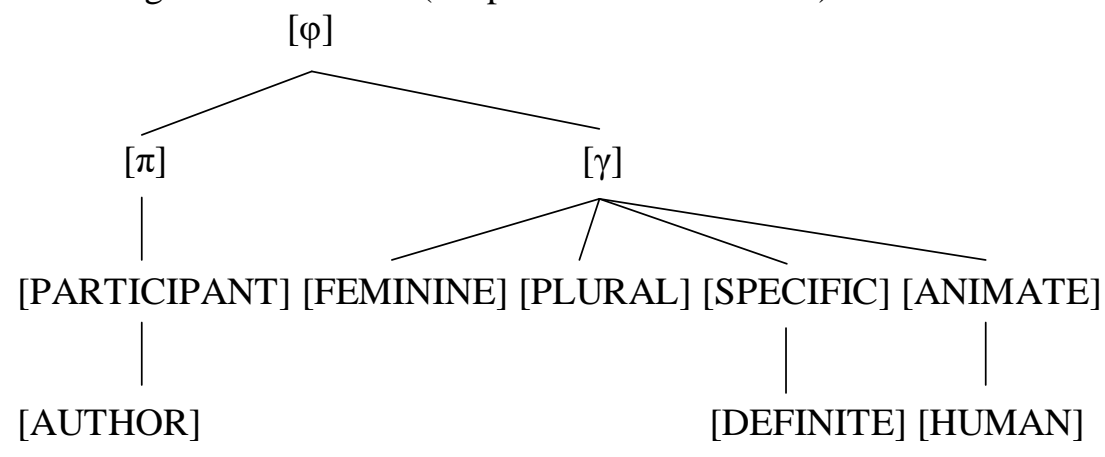

Adopting a basic feature-geometric layout as in (35), we may take valuation in Preminger's terms to be realized as in (35):

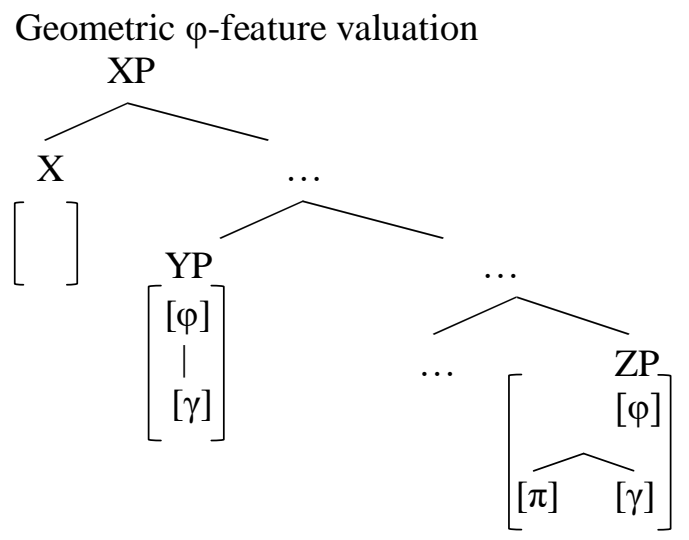

In (36), the functional head $\mathrm{X}^{\circ}$ probes for features of a lower constituent in its c-command domain. Instead of uninterpretable features that must be checked and deleted before reaching the interfaces, $X^{\circ}$ has an "empty container" that will be filled with whichever feature bundle snippet matches its specification. Beyond this, the first available constituent $\mathrm{c}$-commanded by $\mathrm{X}^{\mathrm{o}}$ that bears the desired features will serve as the goal. If it does not, however, $\mathrm{X}^{\mathrm{o}}$ may continue to probe. ${ }^{27}$ Taking the feature-geometric approach here, if the functional head only probes for a particular feature associated with third-person DPs as found in the [ $\gamma]$-bundle (e.g. [+ANIMATE]), YP will serve as the goal. If $\mathrm{X}^{\mathrm{o}}$ is also searching for a feature such as [+PARTICIPANT], however, it will probe past

\footnotetext{
${ }^{26}$ A reviewer asks why [ADDRESSEE] is not within this sketched feature geometry, as it has been shown to play a significant role in many licensing operations. While I agree, I adopt Kalin's (2019) model for expository purposes and recognize that feature geometries may vary from language to language with respect to the exclusive-inclusive distinction they bear (see McGinnis 2005: 702). As none of my examples deal with first- or second-person features, this detail is orthogonal to my investigation.

${ }^{27}$ I do not address what happens when the probe is unable to find a goal, as this part of Preminger's "obligatory-operations model" is not pertinent to my investigation here.
} 
YP, and ZP will serve as the goal. ${ }^{28}$ This understanding of Relativized Minimality (Rizzi 1990) is crucial for our understanding of how nominative case is assigned in VOS sentences: if nominative case is assigned as a reflex of Agree, then the verb on $\mathrm{T}^{\mathrm{o}}$ bypassing the object and finding the subject will result in the subject being assigned nominative case as a reflex of copying its features.

\subsubsection{Is DOM more than just a way to assign case?}

The cases that I have presented thus far of DOM in Galician lead to the assumption that differential marking is an interface strategy that aids in the distinguishing of the subject from the object. This observation seems reasonable given the fact that the subject and object are linearized beside one another, with no intervening material, in constructions in which DOM is licensed. Aissen (2003: 437) addresses the fact that, although it is not always the case, "there may be cases in which DOM is motivated precisely by the need to disambiguate [the subject from object]". While this is clearly not what we find in Spanish as many authors have shown, this does indeed seem to be the case for Galician. Recall that the natural order of postverbal nominal constituents is subject-object (see section 2.2.2). When they are switched (i.e. object-subject), this order is potentially disruptive for reasons beyond those of surface-level intelligibility (see 1011). In the following section, I show that DOM is only licensed in VOS configurations when the object shares the same (or increased) featural specificity as the subject with respect to animacy in order for nominative licensing to proceed.

\subsection{Concluding remarks}

In this section, I have laid out the theoretical underpinnings in order to account for DOM licensing in Galician. Based on observations by Kalin (2018), I claim that objects are licensed by $\mathrm{P}^{\mathrm{o}}$ in order to permit nominative case assignment and feature checking of the final-position subject when both nominals are marked for the same level of animacy. In the next section, I explain the data from Galician based on the feature checking system outlined in Preminger $(2011,2014)$.

\section{Putting together DOM and movement in Galician}

In this section I apply the aforementioned theoretical implications to the data from Galician. I show that unlike other Romance varieties, DOM in Galician surfaces based on particular features present on both postverbal nominals, specifically those of [+ANIMATE] and in some cases [+HUMAN], when found in VOS configurations. I show how DOM is employed in order for the subject in the highlighted VOS strings to be assigned nominative case by $\mathrm{T}^{\mathrm{o}}$ and in order to copy its $\varphi$-set to this functional head.

\footnotetext{
${ }^{28}$ Preminger's account is similar to that of Nevin's (2011) "omnivorous agreement", although he does not use this terminology as "all probes are omnivorous" (2014: 47).
} 


\subsection{How can DOM aid in nominative case assignment?}

Returning to the differential marking on nominals in the cases presented in section 2.2.2, I have shown that only in VOS configurations in which both the subject and object in postverbal position share the feature [+HUMAN] does DOM arise.
a.
Podou
o xardiñeiro a maceira prune.PST.3SG the gardener the apple-tree
b. Podou a maceira o xardiñeiro prune.PST.3SG the apple-tree the gardener 'The gardener pruned the apple tree.'
a.
Recolleron
os pais
os fillos
collect.PST.3PL the parents the children
b. Recolleron ós fillos os pais
collect.PST.3PL DOM-the children the parents
'Parents picked up (their) children).'

In the examples above, DOM is licensed neither in VSO strings in which the subject but not the object is marked [+HUMAN] (37a) nor in VSO strings in which both the subject and object nominals bear an [+HUMAN] feature (38a). The same goes for VOS strings in which the object is inanimate and the subject is marked [+HUMAN] (37b). In $(38 \mathrm{~b})$, however, DOM is obligatory due to the fact that both nominals in the VOS string are marked [+HUMAN].

Further evidence for DOM only appearing when the object nominal precedes the subject postverbally is when one nominal bears an [+ANIMATE] feature and the other bears [+HUMAN]. Take the two VOS examples below:
a.
Perseguía $\quad 0$ can o neno
follow.IMPV.3SG the dog the boy
'The boy chased the dog.'
b. Perseguía ó neno o can
follow.IMPV.3SG DOM-the boy the dog
'The dog chased the boy.'

In (39a), the object $o$ can 'the dog' is not marked with DOM due to the fact that the subject $o$ neno 'the boy' has a further specified feature bundle with a [+HUMAN] feature, distinguishing it from the [+ANIMATE] feature of the object. When the subject and object nominals are switched in (39b), however, the object preceding the subject must be differentially marked in order for $o$ can 'the dog' to provide $\mathrm{T}^{\mathrm{o}}$ with its $\varphi$-set and receive nominative case. I subsequently lay out the specifics of this mechanism based on the process of nominative case assignment explained in section 4.3. 


\subsection{What features matter for DOM and nominative case}

The feature specification of these nominals bears vital importance with respect to the checking of nominative case. For example, if $\mathrm{T}^{\mathbf{o}}$ probes for a nominal that is specified for [+ANIMATE] and the first DP that is encountered holds a [+HUMAN] feature, that will be the nominal that will provide $\mathrm{T}^{\mathbf{o}}$ with its feature copy and will receive case. As we can see from the feature geometric standpoint as laid out in (33), [+HUMAN] bears a further distinction regarding animacy, but any nominal marked [+HUMAN] must be marked [+ANIMATE], as well.

(40) Non-participant feature bundle

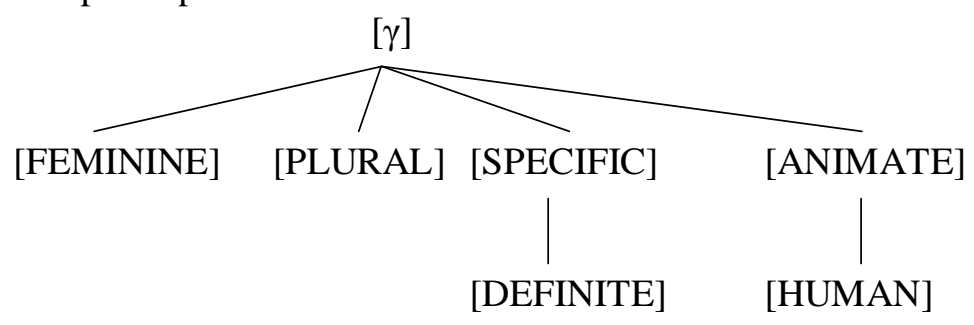

Based on the feature specification in (40), I show how both cases in which the two postverbal nominals bear [+ANIMATE] and those in which one bears a [+HUMAN] feature and the other an [+ANIMATE] feature create the need for DOM to arise in VOS strings.

\subsubsection{DOM and matching feature sets}

Beginning with two postverbal [+ANIMATE] nominals, let us examine the derivational steps by which $\mathrm{T}^{\mathrm{o}}$ receives a copy of the $\varphi$-set of the subject DP and assigns it nominative case in both VSO and VOS sentences.
a. Persegue a gata $o$ rato chase.PRS.3SG the cat the rat
b. Persegue ó rato a gata
chase.PRS.3SG DOM-the rat the cat
'The cat chases the rat.'

Licensing of the VSO string in (41a) is fairly straightforward based on the mechanisms outlined in section 4.3. When the verb complex moves to $\mathrm{T}^{\mathrm{o}}$, it probes for a nominal that bears a particular set of features, notably that of [+ANIMATE]. Due to the fact that $a$ gata 'the cat' is the first caseless DP found with the correct feature specifications, it bequeaths a copy of its features to $\mathrm{T}^{\mathrm{o}}$ and, in turn, receives nominative case. This is shown in (42): 


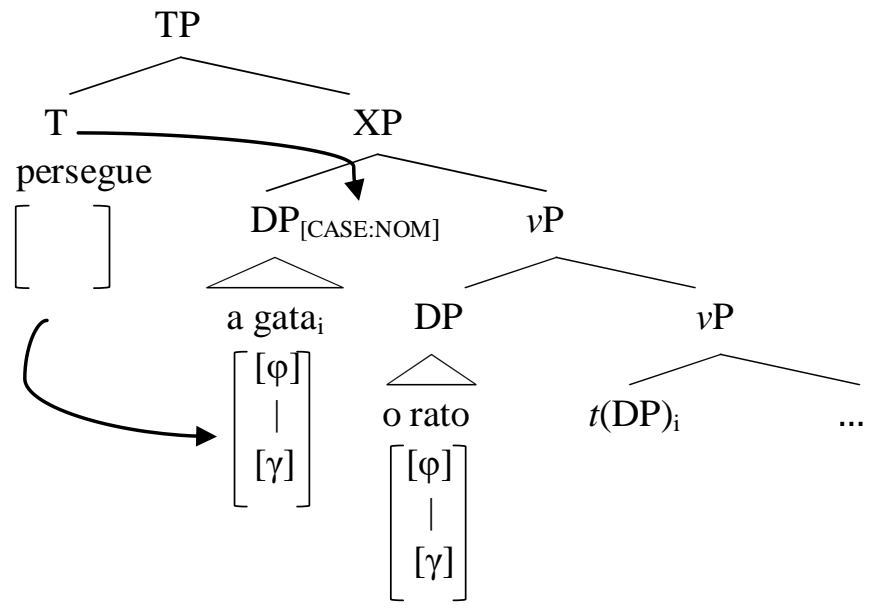

The second nominal, o rato ('the rat'), goes unmarked. Neither abstract licensing nor overt marking is necessary.

When the object precedes the subject as in (41b), however, overt marking on the object nominal is required in order for $\mathrm{T}^{\circ}$ to continue to probe for a viable goal. ${ }^{29}$ Were the object not differentially marked, the result would be ungrammatical.

a.

$$
\begin{aligned}
& \text { *Persegue o rato a gata } \\
& \text { chase.PRS.3SG the rat the cat } \\
& \text { Intended: 'The cat chases the rat.' }
\end{aligned}
$$

b.

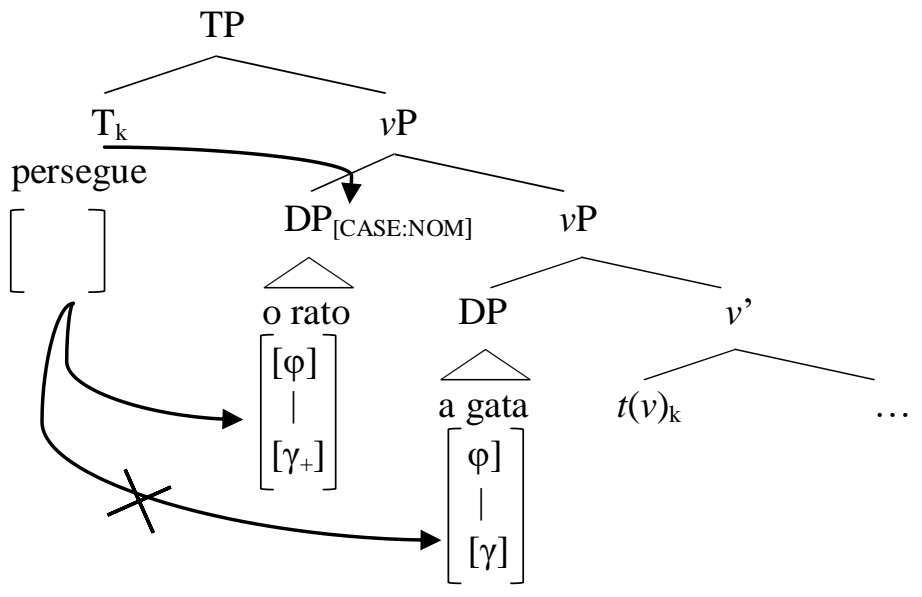

\footnotetext{
${ }^{29}$ A reviewer questions the need for DOM as a last resort strategy and proposes that the subject could very well be licensed "locally by a last resort mechanism". Following the line of thinking that I have laid out above, it seems that this comes down to nominal-marking parametric variation amongst natural languages. There are languages that require differential marking on the subject (de Hoop \& de Swart 2009), languages that require it on the object as I have shown here, and then there are languages that show differential marking on both the subject and object nominal (Arkadiev \& Testelets 2019). This is the line of thought I follow here, although another option is that the subject in VOS does not require licensing at all but is somehow distinguishable from the object based on discourse focus as proposed by Belletti (2001: 64). I leave the comparison of these two approaches for further research.
} 
In (43), $\mathrm{T}^{\mathrm{o}}$ is unable to probe the $\varphi$-set and assign case to the subject nominal a gata 'the cat' after the object $o$ rato 'the rat' has undergone object shift. Based on the principles of relativized probing, $o$ rato 'the rat' will erroneously be assigned nominative case.

In order for $\mathrm{T}^{\mathrm{o}}$ to reach the in-situ subject, the object must be marked. I claim that this is the strategy that Galician employs when two postverbal nominals in a VOS configuration are marked with the same animacy features as in (41b). DOM on the objectshifted nominal permits $\mathrm{T}^{\mathbf{o}}$ to probe past the now case-marked object and assign nominative case to the subject.

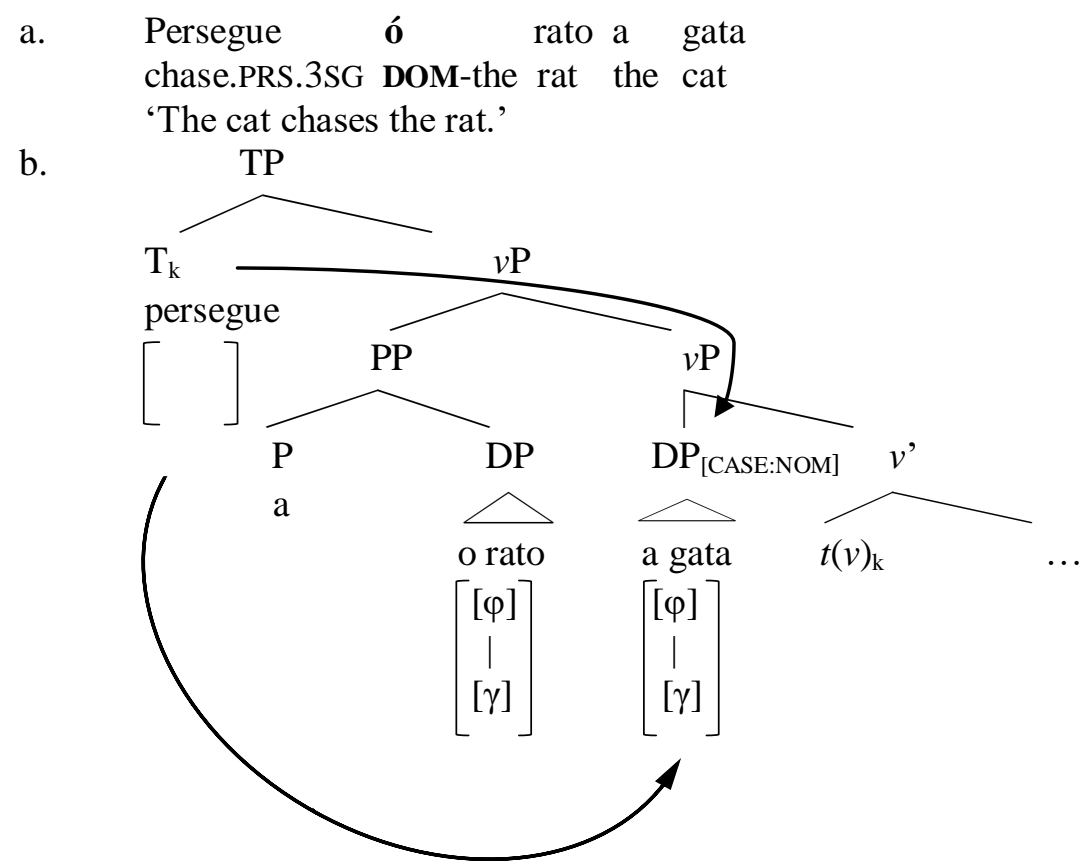

When $\mathrm{T}^{\mathrm{o}}$ probes for a DP in its immediate c-command domain, $o$ rato 'the rat' will be "invisible" to the probe due to the fact that it is embedded within a prepositional phrase, having received overt case by the differential marker $a$ in Galician.

\subsubsection{When animacy is present but not the same}

Where does DOM come into play when animacy is found on both the postverbal subject and object nominals but a featural distinction exists between the two? That is, when one is marked simply [+ANIMATE] and the other bears [+HUMAN]? Let us return to example (39), repeated below in (45).
a. Perseguía
o can o neno
'The boy chased the dog.' 

b.

Perseguía ó neno o can
follow.IMPV.3SG DOM-the boy the dog
'The dog chased the boy.'

As observed previously, both examples in (45) represent VOS strings, although only (45b) requires DOM licensing in order to derive this order. Let us imagine that $\mathrm{T}^{\circ}$ probes for a snippet of feature geometry specified for [+HUMAN]. In (45a), the object-shifted nominal $o$ can 'the dog' will be passed over due to the fact that it only bears the feature [+ANIMATE]. ${ }^{30}$

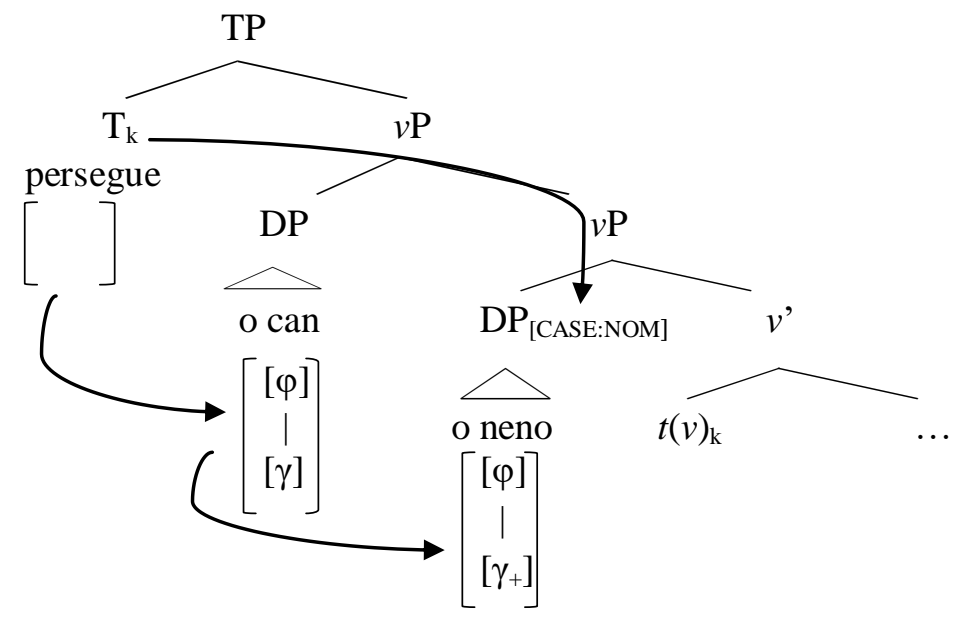

The first DP $\mathrm{T}^{\mathrm{o}}$ finds in its c-command domain is $o$ can 'the dog'. As this nominal does not bear the feature [+HUMAN], it continues to probe until it reaches $o$ neno 'the boy' which does meet its featural specification. In turn, it assigns this DP nominative case and copies its $\varphi$-set.

Upon examining (45b), however, we see that the nominal object $o$ neno 'the boy' is differentially marked. If we imagine that $\mathrm{T}^{\circ}$ probes for a nominal bearing simply [+ANIMATE], both the shifted object $o$ neno 'the boy' and the subject nominal $o$ can 'the dog' meet this featural specification; however, $\mathrm{T}^{\mathbf{o}}$ will be unable to reach $o$ can 'the dog' if o neno 'the boy' precedes it unmarked.

\footnotetext{
${ }^{30}$ I distinguish the feature [+ANIMATE] from [+HUMAN] by using $[\gamma]$ to represent the former and $\left[\gamma_{+}\right]$to represent the latter.
} 


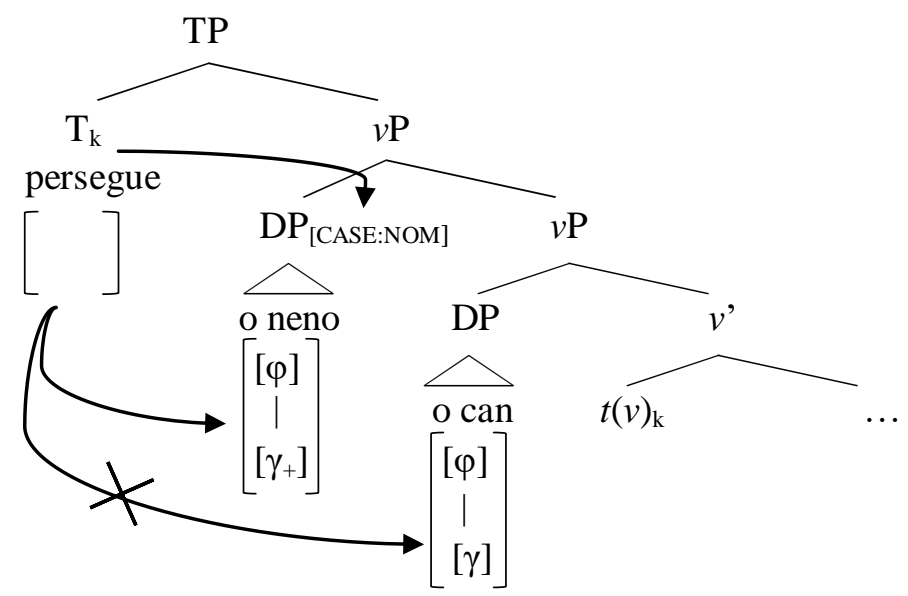

This is a similar situation to that in (43) in which $\mathrm{T}^{\mathbf{o}}$ is unable to probe past the shifted object due to the fact that a) it is unmarked (i.e. it is able to receive case), and b) it meets the feature specifications probed for by $\mathrm{T}^{\circ}$. Just as we showed in (44), the shifted object must be marked in order for the probe on $\mathrm{T}^{\mathrm{o}}$ to reach the subject preceded by the object. $^{31}$

\section{Conclusions}

In this investigation, I have argued for a movement approach in accounting for DOM in Galician. While Galician possesses the ability to license DOM, I have shown that it arises in extremely limited cases directly related to a combination of word order and feature specification. I have provided theoretical evidence for DOM in Galician being solely dependent on animacy (in contrast to Spanish or other languages that employ DOM based on more than one type of "scale"); moreover, I have shown that DOM is licensed on object nominals with an equal or higher animacy specification than that of the subject they precede. My investigation provides clear evidence for a case of DOM that is predicated on movement, a rare motivation for DOM per the observations by Kalin (2018). ${ }^{32}$ This account serves future research regarding the motivations for DOM crosslinguistically as well as forthcoming investigation regarding the variation between DOM in Romance.

${ }^{31}$ A reviewer asks about the appearance of DOM in constructions in which the direct object is spelled-out beside an indirect object with no overt subject as in (i):
(i) Deronlle [o gato] [ó neno]
give.PST.3PL-CL $L_{\text {DAT.3SG }}$ the catat the boy
'They gave the cat to the boy.'

In (i), DOM does not appear on the object nominal $o$ gato, but, as expected in Romance, the indirect object is indeed obligatorily marked with dative case. At first glance, it would appear that Galician does not exhibit the type of lexicalized PCC effects that have been shown for Spanish (Ormazábal \& Romero 2007, 2013) and Romanian (Irimia 2020), although I leave a full account of this for further research.

${ }^{32}$ While I agree with Kalin that many theories of DOM linked to necessary movement are empirically unmotivated (e.g. López 2012 for Spanish), there are cases such as that which I have presented for Galician here, as well as certain Italian varieties (Belletti 2018) and Balearic Catalan (Escandell Vidal 2009), that show necessary movement in accounting for the instances in which DOM surfaces. 


\section{References}

Aissen, J. 2003. Differential Object Marking: Iconicity vs. economy. Natural Language \& Linguistic Theory 21: 435-483.

Álvarez, R. \& Xove, X. 2002. Gramática da lingua galega. Vigo: Editorial Galaxia.

Arkadiev, P. \& Testelets, Y. 2019. Differential nominal marking in Circassian. Studies in Language 43 (3): 715-751.

Belletti, A. 2001. Inversion as focalization. In A. Hulk \& J. L. Pollock (eds.), Subject Inversion in Romance and the Theory of Universal Grammar, 60-90. Oxford: Oxford University Press.

Belletti, A. 2004. Aspects of the Low IP Area. In L. Rizzi (ed.), The structure of CP and IP. The Cartography of Syntactic Strutcures, vol. 2, 16-51. Oxford: Oxford University Press.

Belletti, A. 2017. Labeling (Romance) causatives. In E. Aboh, E. Haeberli, G. Puskás \& M. Schönenberger (eds.), Elements of Comparative Syntax, 13-46. Boston/Berlin: De Gruyter.

Belletti, A. 2018. On a-marking of object topics in the Italian left periphery. In R. Petrosino, P. Cerrone \& H. van der Hulst (eds.), From Sounds to Structures: Beyond the Veil of Maya, 445-466. Boston/Berlin: De Gruyter.

Chomsky, N. 2000. Minimalist inquiries: The framework. In R. Martin, D. Michaels \& J. Uriagereka (eds.), Step by Step: Essays in Minimalist Syntax in Honor of Howard Lasnik, 89-155. Cambridge, MA: MIT Press.

Chomsky, N. 2001. Derivation by phase. In M. Kenstowicz (ed.), Ken Hale: A Life in Language, 1-52. Cambridge, MA: MIT Press.

Ciutescu, E. 2013. Micro-parameter variation in Romance causative constructions. Bucharest Working Papers in Linguistics 2: 45-60.

Colomina, M. P. 2020. VSO order in Romance Languages. Ms.

Costa, J. 2000. Word order and discourse-configurationality in European Portuguese. In J. Costa (ed.), Portuguese Syntax: New Comparative Studies, 94-115. Oxford: Oxford University Press.

Costa, J. 2004. Subject Positions and Interfaces: The Case of European Portuguese. Berlin/New York: De Gruyter.

Danon, G. 2006. Caseless nominals and the projection of DP. Natural Language \& Linguistic Theory 24: 977-1008.

de Hoop, H. \& de Swart, P. 2009. Differential Subject Marking. Dordrecht: Springer.

Diesing, M. 1992. Indefinites. Cambridge, MA: MIT Press.

Escandell Vidal, V. 2009. Differential object marking and topicality. Studies in Language 33 (4): 832-885.

Fox, D. \& Pesetsky, D. 2005. Cyclic linearization of syntactic structure. Theoretical Linguistics 31 (1-2): 1-45.

Freixeiro, X.R. 2006. Gramática galega, vol. II: Morfosintaxe. Vigo: A Nosa Terra.

Gallego, Á. 2013. Object shift in Romance. Natural Language \& Linguistic Theory 31: 409-451.

Gallego, Á. \& Uriagereka, J. 2016. Estar = Ser + X. Borealis: An International Journal of Hispanic Linguistics 5 (1): 123-156.

Gravely, B. 2019. Ditropic cliticization, object shift, and phases: Post-verbal subjects in Galician. Paper presented at Linguistics Symposium of Romance Languages (LSRL) 49, 1-4 May 2019, University of Georgia, Athens, GA

Harley, H. \& Ritter, E. 2002. Person and Number in pronouns: A feature-geometric analysis. Language 78 (3): 482-526.

Holmberg, A. 1986. Word Order and Syntactic Feature in the Scandinavian Languages and English. PhD dissertation, Stockholm University.

Holmberg, A. 1999. Remarks on Holmberg's Generalization. Studia Linguistica 53: 1-39.

Irimia, M. A. 2020. DOM and the PCC: How many types? Paper presented at Linguistics Symposium of Romance Languages (LSRL) 50, 6 July 2020.

Kalin, L. 2018. Licensing and Differential Object Marking: The view from Neo-Aramaic. Syntax 21 (2): 112-159.

Kalin, L. 2019. Nominal licensing is driven by valued (phi-)features. Nordlyd 43 (1): 15-29.

Ledgeway, A., Schifano, N. \& Silvestri, G. 2019. Differential Object Marking and the properties of D in the dialects of the extreme south of Italy. Glossa 4 (1): 1-25.

Lidz, J. 2006. The grammar of Accusative case in Kannada. Language 82 (1): 10-32.

López, L. 2012. Indefinite Objects. Scrambling, Choice Functions, and Differential Marking. Cambridge, MA: MIT Press. 
McGinnis, M. 2005. On markedness asymmetries in Person and Number. Language 81 (3): 699-718.

Mendikoetxea, A. 2008. Clitic impersonal constructions in Romance. Transactions of the Philological Society 106 (2): 290-336.

Nevins, A. 2011. Multiple Agree with clitics: Person complementarity vs. omnivorous number. Natural Language \& Linguistic Theory 29: 939-971.

Ordóñez, F. 2007. Cartography of postverbal subjects in Spanish and Catalan. In S. Baauw, F. Drijkoningen \& M. Pinto (eds.), Romance Languages and Linguistic Theory 2005: Selected Papers from 'Going Romance', 259-280. Amsterdam/Philadelphia: John Benjamins.

Ormazábal, J. \& Romero, J. 2013. Differential Object Marking, Case and Agreement. International Journal of Hispanic Linguistics 2 (2): 221-239.

Ormazábal, J. \& Romero, J. 2019. Prolegomena to the study of object relations. Lingvistica Investigationes $42(1): 102-131$

Preminger, O. 2011. Agreement as a Fallible Operation. PhD dissertation, Massachusetts Institute of Technology.

Preminger, O. 2014. Agreement and its Failures. Cambridge, MA: MIT Press.

Richards, N. 2010. Uttering Trees. Cambridge, MA: MIT Press.

Rizzi, L. 1990. Relativized Minimality. Cambridge, MA: MIT Press.

Rodríguez Mondoñedo, M. 2007. The Syntax of Objects: Agree and Differential Object Marking. PhD dissertation, University of Connecticut.

Sheenan, M., Biberauer, T., Roberts, I., \& Holmberg, A. 2017. The Final-Over-Final Condition. Cambridge, MA: MIT Press.

Zubizarreta, M.L. 1998. Prosody, Focus, and Word Order. Cambridge, MA: MIT Press. 
